SJ Quinney College of Law, University of Utah Utah Law Digital Commons

$2-2019$

\title{
The New Amy, Vicky, and Andy Act: A Positive Step Towards Full Restitution for Child Pornography Victims
}

Paul Cassell

S.J. Quinney College of Law, University of Utah, paul.cassell@law.utah.edu

James R. Marsh

Marsh Law Firm PLLC

Follow this and additional works at: https://dc.law.utah.edu/scholarship

Part of the Criminal Law Commons, and the Criminal Procedure Commons

Recommended Citation

Federal Sentencing Reporter, 31:3 (2019)

This Article is brought to you for free and open access by the Utah Law Scholarship at Utah Law Digital Commons. It has been accepted for inclusion in Utah Law Faculty Scholarship by an authorized administrator of Utah Law Digital Commons. For more information, please contact valeri.craigle@law.utah.edu. 
Forthcoming in Federal Sentencing Reporter, Feb. 2019, Vol. 31, Issue 3

\title{
The New Amy, Vicky, AND ANDy ACt: A Positive Step Towards Full Restitution for CHILD PORNOGRAPHY VICTIMS
}

\author{
Paul G. Cassell ${ }^{*}$ and James R. Marsh ${ }^{* *}$
}

\section{INTRODUCTION}

Providing restitution to victims of child pornography crimes has proven to be a challenge for courts across the country. Child pornography is often widely disseminated to countless thousands of criminals who have a prurient interest in such materials. While the victims of child pornography crimes often have significant financial losses from the crimes (such as the need for long term psychological counseling), allocating a victim's losses to any particular criminal defendant is problematic.

Five years ago, the Supreme Court gave its answer on how to resolve this issue with its ruling in Paroline v. United States. ${ }^{1}$ Interpreting a restitution statute enacted by Congress, the Court concluded that in a child pornography prosecution, a restitution award from a particular defendant is only appropriate to the extent that it reflects "the defendant's relative role in the causal process that underlies the victim's general losses.",

In the ensuing years, lower courts have struggled to implement this holding. Just recently, Congress stepped in to ensure that victims will receive appropriate restitution. In November 2018, the Senate and House resolved their differences in how to handle the issue, passing the Amy, Vicky, and Andy Child Pornography Victim Assistance Act of 2018 (or "AVAA" for short). President Trump signed the legislation into law on December 7, 2018.

In this article, we describe the impact of this important new legislation. We set the stage by describing the need for restitution for child pornography victims, using the story of the lead victim in the Act ("Amy") as an illustration of why restitution is needed. We then turn to the problematic legal regime that was created by the Supreme Court's Paroline decision, noting some of the confusion in the lower courts following the ruling. Against this backdrop, we then discuss the AVAA, explaining how it will be a useful step forward for victims of these crimes.

${ }^{*}$ Ronald N. Boyce Presidential Professor of Criminal Law and University Distinguished Professor of Law at the S.J. Quinney College of Law at the University of Utah.

** Founder, Marsh Law Firm PLLC. The authors thank Patricia Cassell, Jennifer Freeman, Thomas Jipping, Robert Y. Lewis, and Katie Shipp for helpful suggestions in preparing this article.

1572 U.S. 434 (2014).

2 Id. at 458 . 
One even more important possibility is that the Act could set a precedent for expanding restitution for victims in the future.

\section{AMY’S VICTIMIZATION}

The Paroline decision involved not only the named defendant-Randall Doyle Paroline - but also his victim, a young woman whom we will refer to pseudonymously as "Amy." ${ }^{3}$ Her circumstances illustrate the problem of restitution in child pornography cases, and so are worth briefly recounting.

When she was eight and nine years old, Amy was repeatedly raped by her uncle in order to produce child pornography. ${ }^{4}$ Amy's uncle required her to perform sex acts requested by others who wanted her images for their own sexual gratification. Amy's abuser pleaded guilty to production of child pornography and in 1999 was sentenced to a lengthy prison term. He was also ordered to pay the psychological counseling costs Amy had incurred up to that time, a total of $\$ 6,325$.

By the end of her treatment in 1999, Amy was - as reflected in her therapist's notes- "back to normal." Sadly, eight years later, Amy's condition drastically deteriorated when she discovered that her child sex abuse images were at the time one of the most widely-circulated sets of child sex abuse images in the world. According to her psychologist, the global trafficking of Amy's child sex abuse images has caused "long lasting and life changing impact[s] on her." As Amy explained in her own, personal victim impact statement, "[e]very day of my life I live in constant fear that someone will see my pictures and recognize me and that I will be humiliated all over again.,

${ }^{3}$ The authors had the privilege of representing Amy throughout the federal court system in her effort to obtain restitution including before the Supreme Court. Unless otherwise attributed, the facts in this Part are taken from Amy's Supreme Court brief in Paroline. See Respondent Amy's Br. on the Merits, Paroline v. United States, 572 U.S. 434 (2014) (No. 12-8561) [hereinafter Amy's Merits Br.].

${ }^{4}$ While the legal term "child pornography" is used throughout this article, that term "contributes to a fundamental misunderstanding of the crime-one that ... leaves the impression that what is depicted in the[se] photograph[s] is [adult] 'pornography' rather than images memorializing the sexual assault of children." U.S. Dep't of Justice, The National Strategy for Child Exploitation Prevention and Interdiction: A Report to Congress 8 (2010) [hereinafter DOJ REPORT to CONGRESS]. See generally PAul G. CASSELl, JAMES Marsh \& JEREMy Christiansen, Not Just "Kiddie PORN": The REAl HaRms From Possession of Child Pornography, in Refining Child Pornography Law: Crime, Language, And Social Consequence (Michigan Univ. Press 2014); PhiliP Jenkins, Beyond TOLERANCE: CHILD PORNOGRAPHY ON THE INTERNET (2001).

${ }^{5}$ Amy's suffering is similar to that documented in various studies. See, e.g., RICHARD Wortley \& Stephen SMAllbone, InTERnet Child PORNOGRAPHY: CAUSES, InVESTiGATION, AND PREVENTION 73-79 (2012). 
The ongoing victimization Amy suffers from the continued distribution and collection of her images will last throughout her entire life. She could not complete college and finds it difficult to engage in full-time employment because she fears encountering individuals who may have seen her being raped as a child. She will also require weekly psychological therapy and occasionally more intensive inpatient treatment throughout her life.

One of the criminals who joined in the collective exploitation of Amy was Doyle Randall Paroline. In 2008, law enforcement agents discovered that he had downloaded several hundred images of young children (including toddlers) engaging in sexual acts with adults and animals. In 2009, he pleaded guilty to one count of possession of material involving the sexual exploitation of children. ${ }^{6}$

The FBI then sent the images it discovered on Paroline's computers to the National Center for Missing and Exploited Children (NCMEC). NCMEC's analysis revealed that Amy was one of the children victimized in those images. Based on that information, the United States Attorney's Office notified Amy's counsel that Amy was an identified victim in Paroline's criminal case. Amy's counsel then submitted a detailed restitution request on Amy's behalf, describing the harm she endures from knowing that she is powerless to stop the Internet trading of her child sex abuse images. In her restitution request, Amy sought full restitution of $\$ 3,367,854$ from Paroline for lost wages and psychological counseling costs.

Later in 2009, the district court sentenced Paroline to twenty-four months in prison. During a later adversarial restitution hearing, however, the district court, declined to award Amy any restitution. Although the district court recognized that a "significant" part of Amy's losses was "attribut[able] to the widespread dissemination and availability of her images and the possession of those images by many individuals such as [Paroline],", it nonetheless refused to award her any restitution because she could not prove exactly what losses proximately resulted from Paroline's crime.

Amy sought review of the district court's denial of her restitution request, employing the appellate review provision found in the Crime Victims' Rights Act (CVRA). ${ }^{8}$ Ultimately the Fifth Circuit en banc held 10-5 that 18 U.S.C. $§ 2259$ does not require a child pornography victim to establish that her losses were the proximate result of an individual defendant's crime in order to secure restitution. ${ }^{9}$ The Fifth Circuit concluded that $\S 2259$ creates a system of joint and several liability, which "applies well in these circumstances, where victims like Amy are harmed by defendants acting separately who have caused her a single harm."10

${ }^{6}$ See 18 U.S.C. $§ 2252(a)(4)(B)$ (2012) (made a ten-year felony by 18 U.S.C. $\S$ 2252(b)(2) (2012)).

${ }^{7} 672$ F.Supp.2d at 792.

8 18 U.S.C. $\$ 3771(\mathrm{~d})(3)$ (2009).

9 In re Amy Unknown, 701 F.3d 749 (5th Cir. 2012).

10 Id. at 774. 
Paroline sought review in the Supreme Court. Amy agreed that review was appropriate, and the Court then granted certiorari.

\section{THE SUPREME COURT'S PAROLINE DECISION}

In January 2014, Amy participated in oral argument through legal counsel, which itself was unprecedented in a criminal case, where prosecutors and defense attorneys are typically the only advocates allow to speak Amy became the first crime victim to have argument presented directly on her own behalf to the Supreme Court in a criminal case. A few months later, in April 2014, the Supreme Court announced its decision in Paroline. ${ }^{11}$ Justice Kennedy wrote the majority opinion for five members of the Court, rejecting Amy's arguments. Chief Justice Roberts, joined by Justices Scalia and Thomas, dissented, as did Justice Sotomayor.

Justice Kennedy's majority opinion first held that $\S 2259$ imposed a proximate cause requirement on victims attempting to recover restitution for their losses but that it was easily met in this scenario. ${ }^{12}$ While that issue is complicated, ${ }^{13}$ the key part of the opinion for the purposes of this article is the Court's resolution of the issue of how to apply the statute's causation requirements. Justice Kennedy thought that it was "simple enough for the victim to prove the aggregate losses, including the costs of psychiatric treatment and lost income, that stem from the ongoing traffic in her images as a whole." ${ }^{\prime 4}$ He called these losses "general losses" and explained that the challenge is determining what part "of those general losses, if any, that are the proximate result of the offense conduct of a particular defendant who is one of thousands who have possessed and will in the future possess the victim's images but who has no other connection to the victim."

Justice Kennedy then examined whether a "but for" test could be used to identify the losses suffered by a victim as the result of any particular defendant's crime. He concluded that the difficulty with this approach is that a showing of but-for causation cannot be made since "it is not possible to prove that her losses would be less (and by how much) but for one possessor's individual role in the large, loosely connected network through which her images circulate." 16

Justice Kennedy next turned to the causation test identified in the Restatement of Torts for "[m]ultiple sufficient causal sets" causing an injury - such as when

11 Paroline v. United States, 572 U.S. 434 (2014).

12 Id. at 447.

${ }^{13}$ For further discussion of the issue, see generally Paul G. Cassell \& James R. Marsh, Full Restitution for Child Pornography Victims: The Supreme Court's Paroline Decision and the Need for a Congressional Response, 13 OHIO ST. J. CRIM. L. 5 (2015).

14 Paroline, 572 U.S. at 449.

15 Id. at 450.

16 Id. 
three persons lean on a car and the weight of all three is necessary to propel the car off of a cliff. ${ }^{17}$ The Justice explained that such tests "though salutary when applied in a judicious manner, also can be taken too far." 18 He concluded that applying the test in the child pornography context would be "taking things too far," because "[it] would make an individual possessor liable for the combined consequences of the acts of not just 2, 5, or even 100 independently acting offenders; but instead, a number that may reach into the tens of thousands. $" 19$

For all these reasons, Justice Kennedy rejected Amy's argument that an individual possessor should be held responsible for all her losses. But Justice Kennedy also rejected the "anomalous" position that each defendant would be responsible for no restitution at all. ${ }^{20}$ Instead, he held that each defendant should pay some amount of restitution:

In this special context, where it can be shown both that a defendant possessed a victim's images and that a victim has outstanding losses caused by the continuing traffic in those images but where it is impossible to trace a particular amount of those losses to the individual defendant by recourse to a more traditional causal inquiry, a court applying $\S 2259$ should order restitution in an amount that comports with the defendant's relative role in the causal process that underlies the victim's general losses. $^{21}$

Chief Justice Roberts dissenting, joined by Justices Scalia and Thomas. The Chief Justice acknowledged the difficulty of deciding what share of Amy's losses could be attributed to any particular defendant, concluding that "[r]egrettably, Congress provided no mechanism for answering that question."22 He then examined the majority opinion and determined that it will result in tiny awards for Amy, meaning "that Amy will be stuck litigating for years to come." 23 He acknowledged that the majority opinion had cautioned against "trivial restitution orders," but maintained that "it is hard to see how a court fairly assessing this defendant's relative contribution could do anything else." ${ }^{24}$ The Chief Justice concluded with a call for congressional action, explaining that " $[\mathrm{t}]$ he statute as written allows no recovery; we ought to say so, and give Congress a chance to fix it. ${ }^{25}$

17 Id. at 452.

18 Id.

19 Id. at 454.

Id. at 452 .

Id. at 458.

Id. at 467 (Roberts, C.J., dissenting).

Id. at 470 (Roberts, C.J., dissenting).

24 Id. at 471 (Roberts, C.J., dissenting).

25 Id. at 471-72 (Roberts, C.J., dissenting). 
Justice Sotomayor also dissented, essentially agreeing with Amy on every point. She began by arguing that $\S 2259$ created an "aggregate causation" standard, reading the statute as "offer[ing] no safety-in-numbers exception for defendants who possess images of a child's abuse in common with other offenders." 26 Justice Sotomayor found the majority's interpretation fundamentally flawed because the statute "directs courts to enter restitution not for a 'proportional' or 'relative' amount, but rather the 'full amount of the victim's losses.",27 Justice Sotomayor also concluded with a call for Congressional action, noting that "to avoid the uncertainty in the Court's apportionment approach, Congress might wish to enact fixed minimum restitution amounts. ${ }^{28}$

\section{THE UNEVEN IMPLEMENTATION OF THE PAROLINE DECISION}

Following the Court's holding in 2014, lower federal courts throughout the country struggled to implement the Paroline decision in restitution hearings in child pornography cases. The problem with Justice Kennedy's opinion is that it failed to provide any effective guidance on the key question in all of the case: how much restitution should victims like Amy and others should receive. The key passage in the opinion was that "a court applying $\S 2259$ should order restitution in an amount that comports with the defendant's relative role in the causal process that underlies the victim's general losses." ${ }^{29}$ Justice Kennedy cautioned that "[t]hese factors need not be converted into a rigid formula, especially if doing so would result in trivial restitution orders.",30

In cautioning against "trivial" restitution awards, Justice Kennedy appears to have been responding to a concern that Amy raised in the closing paragraphs of her brief. Amy warned that apportioning restitution among multiple defendants will result in "trivial" restitution award. ${ }^{31}$ Amy explained that her images were at that time identified in 3,200 American federal and state criminal cases. She noted that, unfortunately, cases prosecuted at the federal level represent just a fraction of the child pornography criminals who cause her injuries because law enforcement can only apprehend a small fraction of those who distribute and possess the child pornography depicting her. Based on rough calculations, Amy offered the ballpark estimate that Paroline's "market share" of her harm is 1/71,000 and that any individual defendant's restitution obligation to her would be a trifling amount: about $\$ 47$ which was calculated by taking the full amount of her losses $(\$ 3,367,854)$ and then multiplying by $1 / 3,200$ (the total number of cases where her

\footnotetext{
26 Id. at 476 (Sotomayor, J., dissenting).

27 Id. at 480 (Sotomayor, J., dissenting).

28 Id. at 488 (Sotomayor, J., dissenting).

${ }^{29}$ Id. at 458 .

${ }^{30} \mathrm{Id}$.

31 Amy's Merits Br., supra note 3, at 65.
} 
images had been found) and then 1/10 (the ten percent law enforcement apprehension rate) and then 45/100 (the percentage of child pornography criminals who are found in this country). ${ }^{32}$

Chief Justice Roberts' dissenting opinion addressed these troubling numbers. After recounting the computation, Chief Justice Roberts noted the majority's disclaimer that trivial awards were inappropriate, but he concluded, "it is hard to see how a court fairly assessing this defendant's relative contribution could do anything else." 33

Because the Supreme Court offered no guidance on this essential topic, lower courts have had difficulty determining restitution awards for convicted child pornography defendants. As one summary of the caselaw concluded, "Since the Paroline decision, federal courts have struggled to calculate appropriate awards. The Paroline decision has done little to help courts clarify the amount of restitution that victims should be awarded." 34

For example, in the immediate wake of the opinion, the District Court in the Northern District of New York noted that "in the handful of district courts that have grappled with the matter of restitution in child pornography cases postParoline, several have expressed their concern with the lack of precise guidance from Congress and the Supreme Court in deciding restitution awards in these circumstances.... Having now grappled with the same issues, this Court finds that such concerns are well founded." 35 Similarly, the District Court for the District of Rhode Island found that "some of the factors the Supreme Court suggests to be considered are at best difficult, and at worst impossible to calculate in this case as in most similar cases." ${ }^{36}$ The District Court for the District of Nevada agreed that "Paroline is of limited use because no logical starting point can be determined. ${ }^{37}$ More colorfully, the District Court of the Eastern District of New York wrote that "though commentators may quarrel over the astuteness of the Supreme Court's professed confidence in the skill of the district courts to divine a true course through this thicket... the task seems akin to piloting a small craft to safe harbor in a Nor'easter.... The task of charting passage through these unknown waters is

${ }^{32}$ Amy's Merits Br., supra note 3, at $\mathrm{n} .19$ (calculating 3,367,854 x 1/3,200 x 1/10 x $45 / 100 \approx \$ 47)$.

33 Paroline, 572 U.S. at 471 (Roberts, C.J., dissenting).

34 Janet Lawrence, The Peril of Paroline: How the Supreme Court Made It More Difficult for Victims of Child Pornography, 2016 B.Y.U. L. REV. 325, 362 (2016).

${ }^{35}$ United States v. Miner, No. 1:14-CR-33 MAD, 2014 WL 4816230, at *9 (N.D.N.Y. Sept. 25, 2014), vacated in part, 617 F. App'x 102 (2d Cir. 2015).

${ }^{36}$ United States v. Crisostomi, 31 F. Supp. 3d 361, 364 (D.R.I. 2014).

${ }^{37}$ In United States v. Austin, No. 3:14-CR-0070-LRH-WGC, 2015 WL 5224917, at *2 (D. Nev. 2015). 
overwhelming.,"38 Equally noteworthy, several courts explicitly joined Chief Justice Robert's and Justice Sotomayor's calls for Congressional action. ${ }^{39}$

\section{INNOVATIONS AND IMPLICATIONS OF THE AMY, VICKY, AND ANDY ACT}

Against the backdrop of both the difficulty that lower courts were having in implement the Paroline decision and the decision's express call for Congress to step in, it was perhaps inevitable that Congress would pass some sort of legislation addressing restitution in child pornography cases. ${ }^{40}$ And in late 2018 , acting by

${ }^{38}$ In United States v. DiLeo, 58 F. Supp. 3d 239, 244 (E.D.N.Y. 2014). Two years later, the same court employed a different metaphor to describe the difficult of the task, explaining "It should be clear by now for sure that "restitution" in child pornography cases is a minefield." United States v. Darbasie, 164 F. Supp. 3d 400, 406 (E.D.N.Y. 2016). Many other courts reached similar conclusions. See, e.g., United States v. Campbell-Zorn, No. CR 14-41-BLG-SPW, 2014 WL 7215214, at *3 (D. Mont. 2014) ("These tools provided by Paroline, while seemingly useful in a theoretical sense, have proven to have very difficult, and very limited, practical application."); United States v. Ayer, No. 2:15CR-86-APG-NJK, 2015 WL 7259765, at *2 (D. Nev. 2015) ("While the Paroline factors offer some guidance, the practical application of those factors is extraordinarily difficult."); United States v. Miller, No. 13-20928, 2015 WL 6689363, at *2 (E.D. Mich. 2015) ("It is extremely difficult to quantify the loss sustained by these minor victims."); United States v. Reynolds, Crim. No. 12-20843, 2014 WL 4187936, at*5-*6 (E.D. Mich. 2014), aff'd, 626 F. App'x 610 (6th Cir. 2015) (“...it is simply not possible for the Government to show, 'as a starting point,' the amount of losses caused by the 'continuing trafficking' in Cindy and Vicky's images.").

${ }^{39}$ United States v. Schultz, No. 14-10085-RGS, 2015 WL 5972421, at*3 (D. Mass. 2015) (Congressional action "would eliminate much of the present variability in victim restitution awards.”); United States v. Galan, No. 6:11-CR-60148-AA, 2014 WL 3474901, at *8 (D. Or. 2014), vacated and remanded, 804 F.3d 1287 (9th Cir. 2015) ("The current statutory process for restitution does not fully compensate losses suffered by child pornography victims and may, in fact, dissuade victims from seeking restitution; the end result is hardly worth yet another reminder of their continued exploitation. The court cannot remedy this problem. Rather, it is up to Congress to develop a system to truly compensate child pornography victims for the losses they continue to suffer."); United States v. Galan, 804 F.3d 1287, 1291 (9th Cir. 2015) ("We do agree that this area, in which Congress has adopted a scheme that at least approaches the limits of fair adjudication, despite attempts by the courts to avoid caprice, cries out for a congressional solution.").

40 See Professor Richard L. Hasen, Election Law Blog, http://electionlawblog.org/?p=60802 (visited Jan. 10, 2019, posted on April 23, 2014 ("Even though Congress rarely overrides [the Supreme Court] these days, I predict an override in this case, and probably relatively quickly.... this seems the ideal case for a Congressional override."); Dean A Mazzone, Paroline v. United States: The Question of Restitution, 16 ENGAGE, July 15, 2015 ("In the end, Congress will have to fix the statute it wrote. Well intentioned guidance by the Supreme Court is simply no substitute for the hard work of legislating."). 
way of unanimous consent, both the House and Senate approved the "Amy, Vicky, and Andy Child Pornography Victim Assistance Act of 2018," which the President then quickly signed into law. Because the Act significantly changes the way in which child pornography restitution claims are handled, it is useful to review how Congress intended the Act to operate and structured the Act's provisions. The Act makes significant changes in four areas: determining restitution amounts, awarding restitution based on aggregate causation, establishing a fund for victims to access in lieu of individualized awards, and providing victims with access to evidence. We describe and critique the AVAA's changes in each of these four areas in turn.

\section{A. Determining Restitution Awards}

The AVAA restructures the way in which courts will award restitution to victims in child pornography cases. Congress created an umbrella category of "trafficking in child pornography," which includes possession of child pornography and similar crimes. ${ }^{41}$ For these trafficking crimes, a sentencing court will have to make two separate findings when a victim requests restitution. First, "[t]he court shall determine the full amount of the victim's losses that were incurred or are reasonably projected to be incurred by the victim as a result of the trafficking in child pornography depicting the victim." ${ }^{42}$ Second, after making this determination, the court "shall order restitution in an amount that reflects the defendant's relative role in the causal process that underlies the victim's losses, but which is no less than $\$ 3,000 . " 43$ A victim can continue to seek and be awarded restitution in various federal child pornography cases until receiving the full amount of her losses, but no more.

This change, while modest, is important for child pornography victims like Amy, Vicky, and Andy, who have significant losses caused by a huge number of offenders. The AVAA clarifies that losses must be awarded not simply for past, out-of-pocket losses, but also all future losses "reasonably projected to be incurred by the victim."

In addition, Congress establishes a minimum restitution amount of $\$ 3,000$ for trafficking in child pornography cases which can be increased depending on "the defendant's relative role in the causal process that underlies the victim's losses"the so-called Paroline factors. By setting a guaranteed minimum restitution amount (or "floor") of $\$ 3,000$ for child pornography possession and distribution crimes, Congress has ensured that victims with significant losses (such as Amy, Vicky, Andy and others) will be able to begin collecting a series of $\$ 3000$ awards which should ultimately allow victims to achieve full restitution for the losses they

\footnotetext{
${ }^{41} 18$ U.S.C. $\S 2259(\mathrm{c})(3)$.

42 U.S.C. $\$ 2259(\mathrm{~b})(2)(\mathrm{A})$.

43 18 U.S.C. $\S 2259$ (b)(2)(B).
} 
have suffered. By setting a specific minimum amount that must be awarded, the Act should help reduce seemingly interminable litigation about the relative causal role that a particular defendant plays in causing losses along with "trivial" restitution awards.

In light of recent simultaneous changes Congress made to federal sentencing laws in the First Step Act ${ }^{44}$-including the repeal of some mandatory minimum sentencing laws - some observers may wonder whether the two new laws are philosophically inconsistent. Is there a conceptual conflict between establishing mandatory restitution amounts while abolishing (some) mandatory sentences? Any perceived conflict disappears when the AVAA's specific purposes are considered. Mandatory minimum prison terms can sometimes be draconian and blunt, ${ }^{45}$ as some of the AVAA's key sponsors have argued. ${ }^{46}$ But the AVAA does not specify mandatory prison sentences designed to punish offenders. Instead, the AVAA provides minimum restitution amounts designed to compensate injured victims. And defendants will still be able to pay those amounts in an appropriate way over time since nothing in the AVAA alters or supersedes the general provisions in the restitution statute which requires judges to set a reasonable and proportional payment schedule. $^{47}$

A requirement to pay such a modest amount as $\$ 3,000$ should not raise any constitutional concerns, specifically Eighth Amendment "excessive fine" concerns. ${ }^{48}$ Most federal courts agree that restitution is remedial in nature and therefore not subject to Eighth Amendment punishment or "excessive fine" limitations, but a circuit split exists on this issue. ${ }^{49}$ The Paroline decision flagged the possibil-

44 Pub. L. 155-391.

${ }^{45}$ See, e.g., Erik Luna \& Paul G. Cassell, Mandatory Minimalism, 32 CARdozo L. REV. 1 (2010).

${ }^{46}$ See, e.g., Orrin G. Hatch, The Role of Congress in Sentencing: The United States Sentencing Commission, Mandatory Minimum Sentences and the Search for a Certain and Effective Sentencing System, 28 WAKE FOREST L. REV. 185, 192-95 (1993).

${ }^{47} 18$ U.S.C. $\S 3664(\mathrm{f})(1)(\mathrm{A})(2)$.

${ }^{48}$ Nor is there any Sixth Amendment problem with restitution awards being made by judges rather than juries, although at least two Justices on the Court have recently indicated an interest in exploring this subject. See Hester v. U.S., --- U.S. ---, 2019 WL 113622 (Jan. 7, 2019 Mem.) (Gorsuch \& Sotomayor, J.J., dissenting from the denial of certiorari).

${ }^{49}$ Compare, e.g., In re Amy Unknown, 701 F.3d 749, 771-72 (5th Cir. 2012) (en banc) (holding Eighth Amendment not applicable to $\S 2259$ because the purpose of restitution "is remedial, not punitive"), with United States v. Dubose, 146 F.3d 1141, 1144 (9th Cir. 1998) ("[R]estitution under the [Mandatory Victim Restitution Act ("MVRA")] is punishment" and subject to Eighth Amendment limitations "because the MVRA has not only remedial, but also deterrent, rehabilitative, and retributive purposes." (citation omitted)). 
ity that large restitution awards could raise constitutional concerns, while not deciding the issue one way or the other. ${ }^{50}$

The better view on this question is that restitution (at least as provided in the AVAA) is not a punitive measure subject to the Eight Amendment's Excessive Fines Clause, but rather is a compensation regimin designed to restore crime victims. ${ }^{51}$ It is difficult to argue that restitution is a "fine" covered by the Clause, since a "fine" is a "pecuniary criminal punishment or civil penalty payable to the public treasury." 52 Conversely, a restitution award under $\S 2259$ is payable not to the public treasury, but to a crime victim. And the findings that are included in the AVAA make clear that these awards are designed not to punish defendants, but rather to ensure that "victims of child pornography be compensated for the harms resulting from every perpetrator who contributes to their anguish." ${ }^{, 53}$ As Professors Tsachi Keren-Paz and Richard W. Wright have concluded in a thoughtful review of this issue, "as long as the restitution order simply compensates the victim for her actual losses, without any additional extra-compensatory element added for penal purposes, it should not give rise to any constitutional or other issues regarding appropriate punishment, despite the possible deterrent and perhaps rehabilitative effects of the restitution order."

In any event, even if the Constitution's prohibition on excessive "fines" can somehow be contorted to apply to the AVAA's restitution awards, a fine is only excessive if "it is grossly disproportional to the gravity of a defendant's offense." 55 Child pornography felonies are serious crimes punishable by lengthy and in some cases mandatory prison terms. ${ }^{56}$ Against this backdrop, modest restitution awards cannot be viewed as excessive.

While the $\$ 3,000$ requirement for restitution in possession cases is not in any way excessive, the real question concerning the amount is whether it is inadequate. For example, given Amy's losses of more than $\$ 3,000,000$ (outlined earlier), the $\$ 3,000$ minimum restitution amount requires her to file for restitution in more than 1,000 cases, requires courts and probation officers to enter awards and supervise collections, and requires that Amy actually receive that amount.

${ }^{50}$ See 572 U.S. at $455-56$.

${ }^{51}$ See United States v. Visinaiz, 344 F. Supp. 2d 1310, 1318-23 (D. Utah 2004) (Cassell, J.) (explaining why restitution is not punitive. See also Amicus Brief of Vicky and Andy, U.S. v. Paroline, No. 12-8561 (same).

52 Black's Law Dictionary 664 (8th ed. 2004); see United States v. Bajakajian, 524 U.S. 321, 327-28 (1998).

${ }^{53}$ AVAA, Sec. 2(7) (findings).

${ }^{54}$ Tsachi Keren-Paz \& Richard W. Wright, Liability for Mass Sexual Abuse, 56 Aм. CRIM. L. REV. 185 (forthcoming 2018), available at https://papers.ssrn.com/sol3/papers.cfm?abstract_id $=3141016$.

${ }^{55}$ Bajakajian, 524 U.S. at 334.

${ }^{56}$ See, e.g., 18 U.S.C. § 2252(b); 18 U.S.C. § 2252A(b). 
Chief Judge Anne L. Aiken of the District of Oregon, who joined in asking for congressional action to overturn Paroline, clearly pointed out this problem of awarding victims such as Amy just a few thousand dollars. Quoting Chief Justice Roberts dissent, she explained that "'experience shows that the amount in any particular case will be quite small - the significant majority of defendants have been ordered to pay Amy $\$ 5,000$ or less. This means that Amy will be stuck litigating for years to come.' Such piecemeal results hardly remedy the 'continuing and grievous harm' caused by the repeated exploitation of child pornography victims." ${ }^{57}$ For administrative convenience purposes alone, surely a larger amount would be better and more expeditious.

Given the complexities inherent in creating a congressional structure for child pornography restitution awards, it is perhaps understandable the first post-Paroline foray by Congress is somewhat limited. Perhaps district courts will treat the $\$ 3,000$ as simply a floor and begin making substantially higher awards, as Congress has explicitly authorized. But regardless of what courts do, in the future, Congress should significantly increase the minimum award that Amy and other victims can receive.

\section{B. Recognizing the Aggregate Causation Principle}

A sound legal basis now exists for Congress to significantly increase the minimum amounts established in the AVAA. In another innovation, the AVAA recognizes the important principle found in the "aggregate causation standard." In its findings supporting the Act, Congress acknowledged that the "collective conduct" of all person involved in the reproduction, distribution, and possession of child pornography "plays a part in sustaining and aggravating the harms to that individual victim." Congress expressed its intent that "victims of child pornography be compensated for the harms resulting from every perpetrator who contributes to their anguish. Such an aggregate causation standard reflects the nature of child pornography and the unique ways that it actually harms victims."

As Amy argued before the Supreme Court, this aggregate causation standard is well recognized in modern tort law. Tort law, which is often relied upon when considering criminal restitution, has never limited liability based on an individual's "causal relation" to a victim's losses. Instead, tort law has typically considered whether a wrongdoer (i.e., a tortfeasor) has contributed in some way to the victim's larger losses. For example, the American Law Institute has identified contributing cause as a general principle of tort law which is sufficiently well-established to be included in its restatement. As explicated by the American Law Institute's most recent Restatement, "[w]hen an actor's tortious conduct is not a factual cause of

57 United States v. Galan, 6:11-cr-60148-AA, 2014 WL 3474901, at *2 (D. Or. July 11, 2014) (quoting Paroline, 572 U.S. at 457 (Roberts, C.J., dissenting)), rev'd on other grounds, 804 F.3de 1287 ( $9^{\text {th }}$ Cir. 2015). 
harm under the standard in $\S 26$ [i.e., independently sufficient or but-for causation] only because one or more other causal sets exist that are also sufficient to cause the harm at the same time, the actor's tortious conduct is a factual cause of the harm." 58 This approach recognizes for the purposes of tort law that it is often impossible to identify a single "cause" for an event. ${ }^{59}$ In determining tort compensation, the proper question is whether the defendant's crime was part of a "causal set" producing harm - as Paroline's surely was. ${ }^{60}$

Justice Kennedy tacitly acknowledged that these tort law principles supported Amy's position, but maintained that "Congress gave no indication that it intended its statute to be applied in the expansive manner the victim suggests" which would result in holding offenders collectively responsible for "the conduct of thousands of geographically and temporally distant offenders acting independently, and with whom the defendant had no contact." ${ }^{\prime 61}$ Of course, whatever the propriety of Justice Kennedy's interpretation of the statute in 2014, his interpretation not longer applies in 2019 after the AVAA's enactment. Congress has, indeed, now specifically indicated that it intends to impose restitution based on an "aggregate causation" standard, as recognized by the Restatement and encouraged in Justice Sotomayor's dissent.

In doing so, Congress has corrected a mistake the Justice Kennedy made in recounting tort principles. Justice Kennedy recited passages about negligent tortfeasors, overlooking that for intentional tortfeasors "[m] ore liberal rules are applied as to the consequences for which the defendant will be held liable, the certainty of proof required, and the type of damage for which recovery is to be permitted...." ${ }^{62}$ Victims of intentional torts generally do not have to establish a standard proximate cause nexus because "[a]n inquiry into proximate cause has traditionally been deemed unnecessary in suits against intentional tortfeasors."

In construing $\S 2259$ as a tort-like statute, the applicable principles are grounded in intentional torts, not negligent acts. ${ }^{64}$ And in amending the statute, Congress has made it clear that child pornography crimes are like intentional

58 Restatement (ThIRD) OF TORTS: LiABILITY FOR PHYSICAL AND EMOTIONAL HARM $\S 27 \mathrm{cmt}$. f, at 381 (2010) [hereinafter RESTATEMENT].

59 See RESTATEMENT, supra note 58, at $\$ 27 \mathrm{cmt}$. f, Reporters' Note at 391 (collecting authorities discussing this point).

60 See Amy's Brief on the Merits at 50, Paroline v. United States, 572 U.S. 434

(2014) (No. 12-8561) (noting Petitioner Paroline effectively conceded this point).

61572 U.S. at 455.

62 W. Page Keeton et al., Prosser and Keeton on the Law of Torts 37 (5th ed. 1984).

${ }^{63}$ Ass'd Gen. Contractors of Cal., Inc. v. Cal. State Council of Carpenters, 459 U.S. 519, 548 (1983) (Marshall, J., dissenting) (internal citations omitted).

${ }^{64}$ See Paul G. Cassell, James R. Marsh \& Jeremy M. Christiansen, The Case for Full Restitution for Child Pornography Victims, 82 GEO. WASH. L. REV. 61, 101-06 (2013). 
torts. ${ }^{65}$ Accordingly, construing $§ 2259$ as extending liability more broadly for child pornography crimes than standard proximate cause principles would for nonintentional acts, is consistent with, not a departure from, conventional tort theory. ${ }^{66}$

Justice Kennedy's single-minded focus on apportionment seems to stem from the belief that the principle of "full liability" is somehow "disproportionate" to an individual defendant's crime. ${ }^{67}$ But tort law is never proportionate to culpability. A few seconds of inattentive driving can lead to a multi-million-dollar wrongful death judgment. A small tap on an eggshell plaintiff can cause a skull to collapse with huge liability. The overarching tort rule is that a wrongdoer takes his victim as he finds her. ${ }^{68}$ Justice Kennedy only cruelly deviated from that rule because any perceived lack of "proportionality" stems from the fact that Amy has suffered large losses.

The AVAA properly restores the focus of restitution on the victim rather than the defendant. Through its aggregate causation standard and fixed minimum awards, Congress has tried to give substance to the $\S 2259$ 's promise that victims receive restitution for the "full amount" of their losses.

\section{A Defendant-Financed Restitution Fund}

Another Congressional innovation found in the AVAA is a fund through which child pornography victims can receive a one-time fixed amount of compensation. In a new subsection entitled "Defined Monetary Assistance," Congress provides that victims of child pornography trafficking crimes, at their election, can receive $\$ 35,000$ to help them recover. ${ }^{69}$ (The amount is inflation-adjusted in future years.) A victim may only receive this assistance once. To be eligible for such a payment, a district court must determine that the "claimant is a victim of the defendant who was convicted of trafficking in child pornography." If a court makes such a determination, then the victim receives $\$ 35,000$ in defined monetary assistance as specified in the statute.

Payments to victims are made from the Child Pornography Victims Reserve, which is carved out of the much larger federal Crime Victim's Fund. ${ }^{70}$ The Reserve is funded in part by special assessments imposed on convicted child pornography trafficking defendants. The reserve cannot exceed $\$ 10$ million dollars

65 See, e.g., RESTATEMENT (SECOND) OF TORTS $\S$ 652B (1977) (intentional invasion of seclusion); id. $\S 652 \mathrm{D}$ (intentional invasion of privacy); RESTATEMENT, supra note 58, at $\S 46$ (intentional infliction of emotional distress).

${ }^{66}$ For an interesting and extended discussion of the topic, see Tsachi Keren-Paz \& Richard W. Wright, Liability for Mass Sexual Abuse, 56 AM. CRIM. L. REV. 185 (forthcoming 2018), available at https://papers.ssrn.com/sol3/papers.cfm?abstract_id=3141016.

67 Paroline, 572 U.S. at 456.

68 RESTATEMENT, supra note 58, at $\S 31$.

${ }^{69}$ AVAA, Sec. 4 (defined monetary assistance).

${ }^{70}$ See 34 U.S.C. $§ 20101(d)$. 
and can be maintained at that level as a set aside within the Crime Victim's Fund. The assessments imposed on defendants are graduated based on the seriousness of their crime of conviction. Defendants convicted of possession crimes can be assessed "not more than $\$ 17,000$," of any other trafficking crime "not more than $\$ 35,000$," and of production crimes "not more than $\$ 50,000$." The Attorney General will administer the fund and is directed to issue guidelines and regulations to implement this section. The Attorney General is also required to a submit a report to Congress in two years, explaining how the new restitution law has been implemented and assessing the funding levels for the Child Pornography Victims Reserve.

In establishing defined monetary assistance of $\$ 35,000$ (inflation adjusted), Congress implicitly recognized that victims of child pornography face lifetime losses that might not be easily or otherwise be fully compensable. One way to address this problem is to establish or expand government funded programs such as Medicaid which already provide psychological counseling to victims. ${ }^{71}$ But rather than moving in that direction, the AVAA takes the welcome first step of simply giving victims a lump sum amount which they can use however they want.

An important aspect of the Reserve is that it will be financed through special assessments levied against defendants convicted of child pornography crimes. Given the number of federal prosecutions for these crimes, this special assessment could theoretically generate upwards of $\$ 15,000,000$ per year for the Reserve. ${ }^{72}$ This may turn out to be wishful thinking, however, since not all defendants have the financial resources to actually pay the full amount of the assessment. In any case, the Congressional report should answer the question about whether defendant contributions to the Reserve will alone render it self-sustaining. The $\$ 10$ million set aside within the Crime Victims Fund, along with defendant contributions, should render the Reserve capable of providing defined monetary assistance to every victim who applies. But this, too, remains uncertain at this point.

Here again, while Congress' cautiously set the defined amount victims can obtain from the Reserve at just $\$ 35,000$, in the future, armed with additional information about distributions and the viability of defendant contributions, Congress could increase the size of the awards. For example, $\$ 35,000$ is only about

${ }^{71}$ See Warren Binford et al., Beyond Paroline: Ensuring Meaningful Remedies for Child Pornography Victims at Home and Abroad, 35 ChiLD. Legal RTs. J. 117, 133 (2015) ("Despite the efforts of the United States to combat child pornography through a legal framework focused primarily on prosecution, the United States has failed to ensure that child pornography victims experience full physical and psychological recovery and social reintegration.")

72 Some back-of-the-envelope calculations are possible by combing the Sentencing Commission's recent report that about 1800 federal defendants are convicted of child pornography crimes each year. If we assume that these are all possession crimes and that about half will ultimately be able to pay the $\$ 17,000$ special assessment, that generates roughly $\$ 15$ million per year for the fund. 
$1 \%$ of Amy's losses. For other similarly situated victims, there should be a mechanism and the resources available to award substantially more than the $\$ 35,000$ defined amount. Once Congress evaluates how the fund operates, it should consider removing the hard cap of $\$ 35,000$ and allow discretion to fund administrators to award additional dollars to victims who, like Amy, have suffered more sizable losses.

More broadly, Congress should use the Reserve it established for child pornography victims as a model for victims of other federal crimes. While calculating restitution awards for child pornography victims raises some unusual and unique challenges, federal crime victims generally suffer similar difficulties obtaining full restitution for their losses. ${ }^{73}$ Many federal crime victims never recover significant restitution from the offender who victimized them, even if the offender is caught and convicted. ${ }^{74}$

The AVAA creates a compensation fund only for child pornography victims. But the basic fund concept can be easily expanded to other crimes. For serious crimes (such as violent felonies), Congress could simply require all convicted defendants to pay special assessments like those required from convicted child pornography defendants by the AVAA. There can be little doubt that, particularly for violent crimes, substantial special assessments are appropriate and proportionate to the losses that criminals cause their victims. The National Institute of Justice, for example, has derived costs of various violate crimes (in 2008 dollars) reported in the literature. ${ }^{75}$ The figures their derived were $\$ 8.9$ million for murder, $\$ 240,000$ for sexual assault, $\$ 107,000$ for assault, $\$ 42,000$ for robbery, and $\$ 21,000$ for arson. Against this backdrop, requiring every federal defendant convicted of a violent crime to pay a special assessment of $\$ 17,000$ seems eminently reasonable. These assessments could then be used to provide compensation to a much broader group of federal crime victims. ${ }^{76}$

\section{A Right to Evidence Provision}

${ }^{73}$ See, e.g., Alanna D. Francois, Paroline v. United States: Mandatory Restitution an Empty Gesture, Leaving Victims of Child Pornography Holding the Bag, 42 S.U. L. REV. 293, 336-37 (2015) (explaining how lack of restitution for child pornography victims is simply part of a larger problem).

${ }^{74}$ See generally U.S. GOV'T ACCOUNTABILITY OFFICE, GAO-18-203, FEDERAL CRIM-

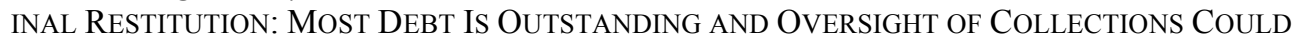
BE IMPROVED (2018).

${ }^{75}$ Kathryn E. McCollister, The Cost of Crime to Society: New Crime-Specific Estimates for Policy and Program Evaluation, 108 DRUG AlCOHOL. DEPEND. 98 (2010).

${ }^{76}$ See generally U.S. GOV'T ACCOUNTABILITY OFFICE, GAO-18-115, FEDERAL CRIMINAL RESTITUTION: FACTORS TO CONSIDER FOR A POTENTIAL EXPANSION OF FEDERAL COURTS' Authority TO ORDER RESTITUTION (2017). 
A final crucial innovative provision in the AVAA creates a victim's "right to evidence." Congress provided that in any criminal proceeding, a victim "shall have reasonable access to any property or material that constitutes child pornography" that depicts the victim." 77 The provision allows the victim (or her attorney or an expert witness) to view the materials depicting that victim, provided that under "no circumstances may such child pornography be copied, photographed, duplicated, or otherwise reproduced."

This statute gives victims the same right to review evidence in their case that defendants currently possess. Defense attorneys, of course, can review the evidence involved in a child pornography prosecution. Victims now have the same right to essential information about their crime, permitting them to vindicate their rights in the criminal proceeding.

This access to evidence provision also gives victims the opportunity to pursue civil relief against defendants. Even though a criminal conviction generally estops a defendant from contesting liability in a subsequent civil case, it has sometimes been difficult for child pornography victims to prove that a defendant specifically possess pornography depicting them. The new provision should facilitate that proof, allowing victims to take advantage of civil causes of action, including the $\$ 150,000$ presumed damages provision already found in Masha's law. ${ }^{78}$

\section{CONCLUSION}

In this article, we have reviewed some of the valuable steps forward found in the AVAA, as well as the work that remains to be done. But in closing, it may be useful to remember that the legal issues swirling around restitution decisions have real world consequences, both for the defendants who must pay the restitution awards and the victims who need and deserve compensation. As between these two groups, however, the equities tip decisively in favor of victims. ${ }^{79}$ To be sure, large restitution awards have financial consequences for criminal defendants. ${ }^{80}$ But the stark fact remains that criminals have a choice to commit the crime or not. Having voluntarily chosen to commit a crime producing serious lifelong financial repercussions for victims, a defendant has no right to complain when courts require him to contribute to making victims whole. Victims of child pornography crimes - and,

${ }^{77}$ AVAA, Sec. 6 (Child Pornography Victim's Right to Evidence).

${ }^{78}$ See James Marsh, Masha's Law: A Federal Civil Remedy for Child Pornography Victims, 61 SYRACUSE L. REV. 459 (2011).

${ }^{79}$ See generally Robyn Holder, Just InTERests: Victims, Citizens AND THE Potential FOR Justice 211-22 (2018). $C f$. Tyrone KirChEngast, Victimology and Victims' Rights: InTERnAtional COMPARATIVE PERSPECTIVES 92-93 (2017) (noting increasing recognition of need for restitution in many countries).

${ }^{80}$ See, e.g., Shima Baradaran Baughman, The Bail Book: A Comprehensive LOOK AT BAIL IN AMERICA’s CRIMINAL JUSTICE SYSTEM 126 (2018). 
more broadly, all serious federal crimes - deserve to have their interests prioritized in federal sentencing statutes. The AVAA is a modest but useful step in that direction. 